\title{
A novel technique using a subcutaneously pedicled islanded prolabial flap for the secondary correction of bilateral cleft lip and nasal deformity
}

\author{
Nitin J. Mokal1 ${ }^{1,2,3,4}$, Mahinoor Feroze Desai ${ }^{3,4}$ \\ ${ }^{1}$ Department of Plastic Surgery, G T Hospital, ${ }^{2}$ Department of Plastic Surgery, Bombay Hospital Institute of Medical Sciences, \\ ${ }^{3}$ Department of Plastic Surgery, Shushrusha Hospital, ${ }^{4}$ Department of Plastic Surgery, Bhatia Hospital, Mumbai, Maharashtra, \\ India
}

Address for correspondence: Dr. Mahinoor Feroze Desai, C/12, Khalakdina Terrace, August Kranti Marg, Mumbai - 400 036, Maharashtra, India. E-mail: mahinoordesai@icloud.com

\section{ABSTRACT}

Context: The bilateral cleft lip and nose deformity frequently requires lip revision surgery at the time of secondary rhinoplasty. The goal is to achieve an adequate philtrum with a well-shaped Cupid's bow, white roll alignment and a central vermilion tubercle. Aims: We have devised a new technique of using prolabial tissue tailored as an island of skin based on a subcutaneous pedicle for the secondary reconstruction of the philtral aesthetic unit in patients with bilateral cleft lip nasal deformity. Settings and Design: This technique was used in 21 patients from March 2012 to August 2015. All patients had undergone primary lip repair at other institutions and required lip revision with simultaneous rhinoplasty. Subjects and Methods: The objective criteria considered in the post-operative evaluation by the authors included improvement of philtral ridge projection, symmetry of philtral column and nasal sill and white roll continuity. The ten individual parameters were given a score from 1 to 4 (with 1 = lowest and $4=$ highest for each individual parameter) and the total score was rated as $31-40=$ excellent, $21-30=$ good, $11-20=$ fair and $0-10=$ Poor. The patients' overall satisfaction was assessed at 6 months postoperatively to record their impression of the aesthetic improvement after our procedure. Results: The follow-up period ranged from 6 months to 3 years. The prolabial flap had no post-operative complications. The authors' assessment judged $15(71.4 \%)$ patients as having an excellent outcome and $6(28.5 \%)$ patients as having a good outcome. All patients expressed subjective satisfaction with the post-operative appearance of their upper lip and rated their results as improved and overall satisfaction scoring was high. Conclusions: This technique is a new addition to the repertoire of procedures which already exist for the correction of bilateral cleft lip nose deformity. It is safe, reliable and has a good aesthetic outcome with no significant morbidity.

\begin{tabular}{|l|l|}
\hline \multicolumn{2}{|c|}{ Access this article online } \\
\hline Quick Response Code: & Website: \\
\hline & www.ijps.org \\
\cline { 2 - 2 } & Dol: \\
\hline
\end{tabular}

This is an open access article distributed under the terms of the Creative Commons Attribution-NonCommercial-ShareAlike 3.0 License, which allows others to remix, tweak, and build upon the work non-commercially, as long as the author is credited and the new creations are licensed under the identical terms.

For reprints contact: reprints@medknow.com

How to cite this article: Mokal NJ, Desai MF. A novel technique using a subcutaneously pedicled islanded prolabial flap for the secondary correction of bilateral cleft lip and nasal deformity. Indian J Plast Surg 2017;50:251-9. 
Mokal and Desai: Islanded pedicle flap technique for secondary correction of bilateral cleft lip nasal deformity.

\section{KEYWORDS}

Bilateral cleft lip secondary deformity; islanded prolabial flap; philtral aesthetic unit; simultaneous lip revision and rhinoplasty

\section{INTRODUCTION}

he bilateral cleft lip nasal deformity is a challenge to the surgeon both at the time of primary repair and at the time of secondary revision. The deformity is as much the result of primary hypoplasia and dysmorphogenesis as it is a consequence of what Mulliken terms the fourth dimension i.e., growth..$^{[1]}$ Over the years, there has been a shift in operative strategy from staged primary repairs with emphasis on lip closure alone, towards primary nasal correction at the time of lip repair ${ }^{[2]}$ so that tissues are placed in their normal anatomical positions as early as possible. ${ }^{[3]}$ However, skilful the primary repair, many patients still require nasal correction and philtral reconstruction at a later date. Often, patients present at cleft care centres like ours having already had multiple 'revision' operations.

The most frequent lip deformity is asymmetry or deficiency of the philtrum and median tubercle, irregularity or notching of the vermilion, the so-called 'whistle deformity', caused by inadequate approximation of the pars marginalis portion of the orbicularis oris muscle, lateral bulges on lip animation due to the unbalanced contraction of the lateral muscle segments or a philtrum that is too wide, which occurs if it was designed wider than $5 \mathrm{~mm}$ at the time of primary lip repair. The characteristic nasal deformities are a short columella, flat and broad nasal tip, wide nostril floors, drooping and flaring alae nasi and scarred nostril sills.

Several methods have been described over the years for the correction of these deformities with varied outcomes. Still elusive, however, is our capability to construct an aesthetically appealing philtral dimple and flanking columns. ${ }^{[2]}$ After evaluating our outcomes with various operative techniques over the past 15 years, the senior author (NJM) devised what we believe to be a new technique of philtral reconstruction using an islanded prolabial flap (IPF) based on a subcutaneous pedicle. To our knowledge, this technique has not yet been published in the literature. We have been using this technique over the past 3 years in selected patients and feel that this modification gives good philtral aesthetics and overcomes some of the shortcomings of the existing methods for the simultaneous correction of the lip and nose deformity.

\section{SUBJECTS AND METHODS}

Over a 3-year period from March 2012 to August 2015, 35 patients with secondary bilateral cleft lip nasal deformity requiring correction were seen at our centre. All patients were first evaluated for oronasal/palatal fistula, alveolar bone gaps and underlying skeletal deformities which were identified and corrected before scheduling the final lip nose revision surgery. Of these patients, 21 patients, comprising 7 males and 14 females, were selected for surgery using our new technique of lip revision with concomitant rhinoplasty [Table 1].

\section{Inclusion criteria}

Inclusion criteria for our technique were as follows:

1. Lip deformity requiring recreation of the Cupid's bow, white roll realignment and creation of a vermilion pout

2. Lateral lip bulges requiring orbicularis oris muscle sling reconstruction

3. Adequate width and height of prolabial tissue

4. Adequate lateral lip elements

5. Nasal deformity requiring an open approach to increase tip projection and provide cartilage support

6. Short columella requiring elongation.

\section{Exclusion criteria}

1. Inadequate prolabial tissue, namely tight and short lip 2. Severely scarred midline tissues.

The patients ranged in age from 12 to 32 years. The primary lip repair had been done at other institutions in all $(100 \%)$ of these patients.

Only two patients were $<17$ years of age. One was a 13-year-old girl and the other two were boys, aged 12 and 14 years, respectively. The 12-year-old boy also underwent a concomitant alveolar bone grafting. In all these children, the severity of the lip and nasal deformity was severe enough to warrant an early rhinoplasty.

Outcomes were documented based on patient satisfaction and retrospective evaluation of pre- and post-operative 
Mokal and Desai: Islanded pedicle flap technique for secondary correction of bilateral cleft lip nasal deformity.

Table 1: Patient details

\begin{tabular}{|c|c|c|c|c|c|c|c|c|c|c|}
\hline $\begin{array}{l}\text { Patient } \\
\text { number }\end{array}$ & Name & $\begin{array}{c}\text { Age } \\
\text { (years) }\end{array}$ & Sex & Deformity & Procedure & Date of surgery & $\begin{array}{l}\text { Follow-up } \\
\text { (months) }\end{array}$ & $\begin{array}{l}\text { Primary } \\
\text { repair }\end{array}$ & $\begin{array}{c}\text { OGS/ } \\
\text { procedure }\end{array}$ & $\begin{array}{c}\text { Interval } \\
\text { to IPF } \\
\text { (months) }\end{array}$ \\
\hline 1 & PC & 23 & Female & Incomplete BLCP & Lip revision & 23 December, 2014 & 8 & $\begin{array}{l}\text { Other } \\
\text { centre }\end{array}$ & Nil & \\
\hline 2 & $M$ & 19 & Female & Complete BLCP & $\begin{array}{l}\text { Lip revision, } \\
\text { rhinoplasty }\end{array}$ & 12 November 2014 & 9 & $\begin{array}{l}\text { Other } \\
\text { centre }\end{array}$ & Nil & \\
\hline 3 & AJ & 23 & Male & Complete BLCP & $\begin{array}{l}\text { Lip revision, } \\
\text { rhinoplasty }\end{array}$ & 02 October 2014 & 10 & $\begin{array}{l}\text { Other } \\
\text { centre }\end{array}$ & Nil & \\
\hline 4 & SP & 18 & Female & Complete BLCP & $\begin{array}{l}\text { Lip revision, } \\
\text { rhinoplasty }\end{array}$ & 14 August 2014 & 12 & $\begin{array}{l}\text { Other } \\
\text { centre }\end{array}$ & Nil & \\
\hline 5 & NJ & 19 & Male & Complete BLCP & $\begin{array}{l}\text { Lip revision, } \\
\text { rhinoplasty, } A B G\end{array}$ & 01 July 2014 & 13 & $\begin{array}{l}\text { Other } \\
\text { centre }\end{array}$ & Nil & \\
\hline 6 & PG & 21 & Female & Complete BLCP & $\begin{array}{l}\text { Lip revision, } \\
\text { rhinoplasty }\end{array}$ & 25 June 2014 & 14 & $\begin{array}{l}\text { Other } \\
\text { centre }\end{array}$ & Nil & \\
\hline 7 & $\mathrm{JN}$ & 32 & Female & Complete BLCP & $\begin{array}{l}\text { Lip revision, } \\
\text { rhinoplasty }\end{array}$ & 21 May 2014 & 15 & $\begin{array}{l}\text { Other } \\
\text { centre }\end{array}$ & Nil & \\
\hline 8 & JK & 16 & Female & Complete BLCP & $\begin{array}{l}\text { Lip revision, } \\
\text { rhinoplasty }\end{array}$ & 03 May 2014 & 15 & $\begin{array}{l}\text { Other } \\
\text { centre }\end{array}$ & Nil & \\
\hline 9 & $\mathrm{NF}$ & 18 & Female & Complete BLCP & $\begin{array}{l}\text { Lip revision, } \\
\text { rhinoplasty }\end{array}$ & 23 April 2014 & 16 & $\begin{array}{l}\text { Other } \\
\text { centre }\end{array}$ & Nil & \\
\hline 10 & PR & 23 & Female & Complete BLCP & $\begin{array}{l}\text { Lip revision, } \\
\text { rhinoplasty }\end{array}$ & 03 July 2013 & 25 & $\begin{array}{l}\text { Other } \\
\text { centre }\end{array}$ & $\begin{array}{c}\text { LeFortl } \\
\text { advancement }\end{array}$ & 6 \\
\hline 11 & VS & 14 & Male & Complete BLCP & $\begin{array}{l}\text { Lip revision, } \\
\text { rhinoplasty }\end{array}$ & 05 June 2013 & 26 & $\begin{array}{l}\text { Other } \\
\text { centre }\end{array}$ & Nil & \\
\hline 12 & $\mathrm{O}$ & 12 & Male & Complete BLCP & $\begin{array}{l}\text { Lip revision, } \\
\text { rhinoplasty, } A B G\end{array}$ & 24 May 2013 & 27 & $\begin{array}{l}\text { Other } \\
\text { centre }\end{array}$ & Nil & \\
\hline 13 & $\mathrm{RP}$ & 18 & Male & Complete BLCP & $\begin{array}{l}\text { Lip revision, } \\
\text { rhinoplasty }\end{array}$ & 19 March 2013 & 29 & $\begin{array}{l}\text { Other } \\
\text { centre }\end{array}$ & Nil & \\
\hline 14 & SB & 23 & Female & Complete BLCP & $\begin{array}{l}\text { Lip revision, } \\
\text { rhinoplasty }\end{array}$ & 12 December 2012 & 32 & $\begin{array}{l}\text { Other } \\
\text { centre }\end{array}$ & Nil & \\
\hline 15 & $\mathrm{BP}$ & 19 & Female & Complete BLCP & $\begin{array}{l}\text { Lip revision, } \\
\text { rhinoplasty }\end{array}$ & 27 November 2012 & 33 & $\begin{array}{l}\text { Other } \\
\text { centre }\end{array}$ & Nil & \\
\hline 16 & RW & 18 & Female & Complete BLCP & $\begin{array}{l}\text { Lip revision, } \\
\text { rhinoplasty }\end{array}$ & 29 May, 2012 & 39 & $\begin{array}{l}\text { Other } \\
\text { centre }\end{array}$ & Nil & \\
\hline 17 & SR & 17 & Female & Complete BLCP & $\begin{array}{l}\text { Lip revision, } \\
\text { rhinoplasty }\end{array}$ & 09 May 2012 & 39 & $\begin{array}{l}\text { Other } \\
\text { centre }\end{array}$ & Nil & \\
\hline 18 & AS & 19 & Male & Complete BLCP & $\begin{array}{l}\text { Lip revision, } \\
\text { rhinoplasty }\end{array}$ & 25 May 2012 & 39 & $\begin{array}{l}\text { Other } \\
\text { centre }\end{array}$ & Nil & \\
\hline 19 & AS & 13 & Female & Complete BLCP & $\begin{array}{l}\text { Lip revision, } \\
\text { rhinoplasty }\end{array}$ & 13 April 2012 & 40 & $\begin{array}{l}\text { Other } \\
\text { centre }\end{array}$ & Nil & \\
\hline 20 & SR & 15 & Female & Complete BLCP & $\begin{array}{l}\text { Lip revision, } \\
\text { rhinoplasty }\end{array}$ & 23 March 2012 & 41 & $\begin{array}{l}\text { Other } \\
\text { centre }\end{array}$ & Nil & \\
\hline 21 & YS & 21 & Male & Complete BLCP & $\begin{array}{l}\text { Lip revision, } \\
\text { rhinoplasty }\end{array}$ & 07 March 2012 & 41 & $\begin{array}{l}\text { Other } \\
\text { centre }\end{array}$ & $\begin{array}{c}\text { LeFortl } \\
\text { advancement }\end{array}$ & 8 \\
\hline
\end{tabular}

photographs by the authors. The objective criteria considered in the evaluation by the authors included improvement of philtral ridge projection, symmetry of philtral column and nasal sill and white roll continuity. The ten individual parameters were given a score from 1 to $4(1=$ lowest and $4=$ highest for each individual parameter) and the total score was rated as follows: 31-40 = excellent, $21-30=$ good, $11-20=$ fair and $0-10=$ Poor. The patients' overall satisfaction was assessed at 6 months postoperatively to record their impression of the aesthetic improvement after our procedure.

\section{Surgical technique}

General anaesthesia is administered with a cuffed endotracheal tube (preformed south polar curvature) secured in the midline of the lower lip. The new philtrum is marked as an aesthetic unit as shown in Figure 1a and $b$. The dimensions are determined as per anthropometric markings for our population base. ${ }^{[4]}$ The lip and nose are infiltrated with a solution containing adrenaline ( 1 in 500,000 dilution), $20 \mathrm{cc}$ of $2 \%$ xylocaine, $20 \mathrm{cc}$ of $0.5 \%$ bupivacaine and hyaluronidase ( $1500 \mathrm{IU}$ ) in $500 \mathrm{cc}$ of Ringer's lactate, volume appropriate for the weight of the patient was utilised from this solution. Bilateral 
Mokal and Desai: Islanded pedicle flap technique for secondary correction of bilateral cleft lip nasal deformity.

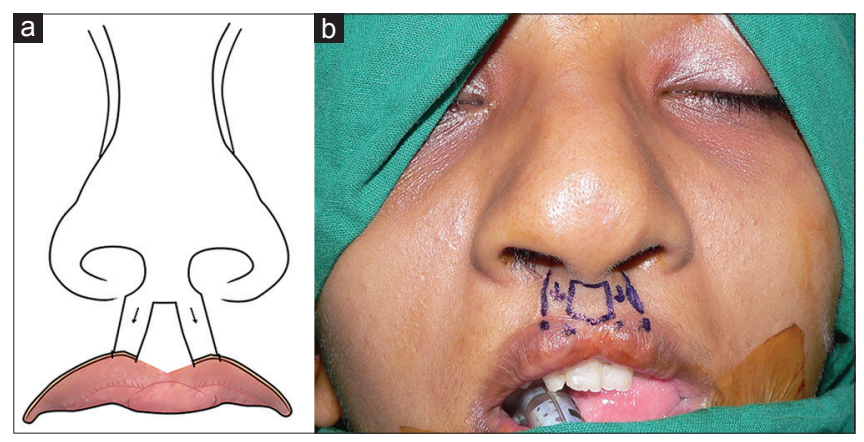

Figure 1: $(a$ and $b)$ Marking the philtral unit and forked flaps

infraorbital nerve blocks were also given with $2 \mathrm{ml}$ of a $1: 1$ mixture of $0.25 \%$ bupivacaine and $1 \%$ xylocaine with adrenaline, for each side.

The forked flaps from either side of the new prolabial unit are raised and continued as part of the open rhinoplasty incision from the lip columellar junction, onto the sides of the columella and bilateral rim incisions. Alternatively, banked forked flaps can be raised for use in columellar elongation [Figure 2a]. A Potter's $\mathrm{V}-\mathrm{Y}$ release of the alar cartilages is performed allowing superomedial repositioning of the slumped and splayed alar cartilages. ${ }^{[5]}$ The nasal skin envelope is elevated over the dorsum and alar cartilages. Excess subcutaneous fibrofatty tissue is trimmed. Dissection between the medial crura of the alar cartilages is carried out to identify the lower border of the septum, and the entire septum is exposed in the subperichondrial plane. Septal cartilage is harvested leaving behind an L-shaped strut for support. The cartilage graft is divided into three pieces, one for the columellar strut and remaining two as alar batten grafts. Occasionally, when dorsal nasal augmentation is also required, additional cartilage may be needed in the form of conchal or costochondral grafts.

The medial crura are fixed to the cartilaginous strut with 4-0 polydioxanone $\left(\mathrm{PDS}^{\circledR}\right)$ sutures, and additional interdomal sutures are passed between the two alar cartilages and the top of the strut to produce the desired amount of tip projection [Figure $2 \mathrm{~b}$ ]. Lateral osteotomies are performed through pyriform rim incisions when required (two patients in this series). The nostril size is assessed, and a Y-V medial advancement of the alar bases is done when required. A 3-0 PDS ${ }^{\circledR}$ alar cinch suture is used to maintain the narrowing of the flared nostrils. The shortened columella was lengthened using the forked flaps in 18 patients. ${ }^{[6,7]}$ In the remaining two patients, the same forked flaps were used as inferiorly based de-epithelialised flaps and turned downwards and buried to give added bulk to the vermilion

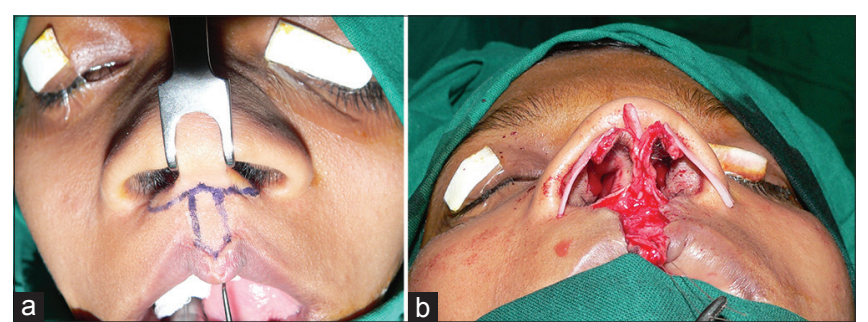

Figure 2: (a) Marking for banked forked flaps along with the island prolabial flap. (b) Open rhinoplasty with columellar strut and bilateral alar batten grafts in the same patient

tubercle. An assessment is made of the residual alar web. This overhanging skin in the soft triangle area is marked and raised from the medial end, keeping its lateral attachment intact. We do this only at the very end while closing the rhinoplasty incisions, so the raised skin flap can be used to fill in the nasal lining defect left behind by the superomedial movement of the composite chondro-mucosal flaps of the lateral crus mentioned earlier. ${ }^{[8]}$

A prolabial flap of the required dimensions is raised as an aesthetic unit based on a subcutaneous pedicle at its lower portion near the vermilion-cutaneous junction [Figure 3a and $b$ ]. The orbicularis oris pars peripheralis muscles of the lateral lip elements are dissected from the overlying skin and any residual abnormal attachments to the piriform rim or nasal vestibular lining. After adequate mobilisation, the muscles are approximated in the midline with 3-0 PDS ${ }^{\circledR}$ sutures, recreating the orbicularis sling above the prolabial flap pedicle. The lateral orbicularis marginalis muscle flaps along with the white roll and vermilion are incised as a lateral advancing flap for reconstruction of the Cupid's bow beneath the prolabium.

The highest points of the Cupid's bow are sutured first followed by approximation of the white roll flaps in the midline so as to recreate the central tubercle and Cupid's bow [Figure $3 c$ and d]. 5-0 PDS ${ }^{\circledR}$ intradermal sutures are used for the key stitches and 5-0 rapide Vicryl ${ }^{\circledR}$ (irradiated polyglactin 910) for the skin. In two patients who did not require extra skin for columellar elongation, the lateral prolabial flaps were raised based on the vermilion margin and subsequently de-epithelialised and used for vermilion augmentation.

Intranasal packing is done using paraffin gauze. Sterile paper tapes are applied over the dorsum for re-draping of the skin envelope over the new cartilaginous framework.

Cold compresses are applied during the post-operative period to reduce oedema and pain. Intravenous antibiotic 


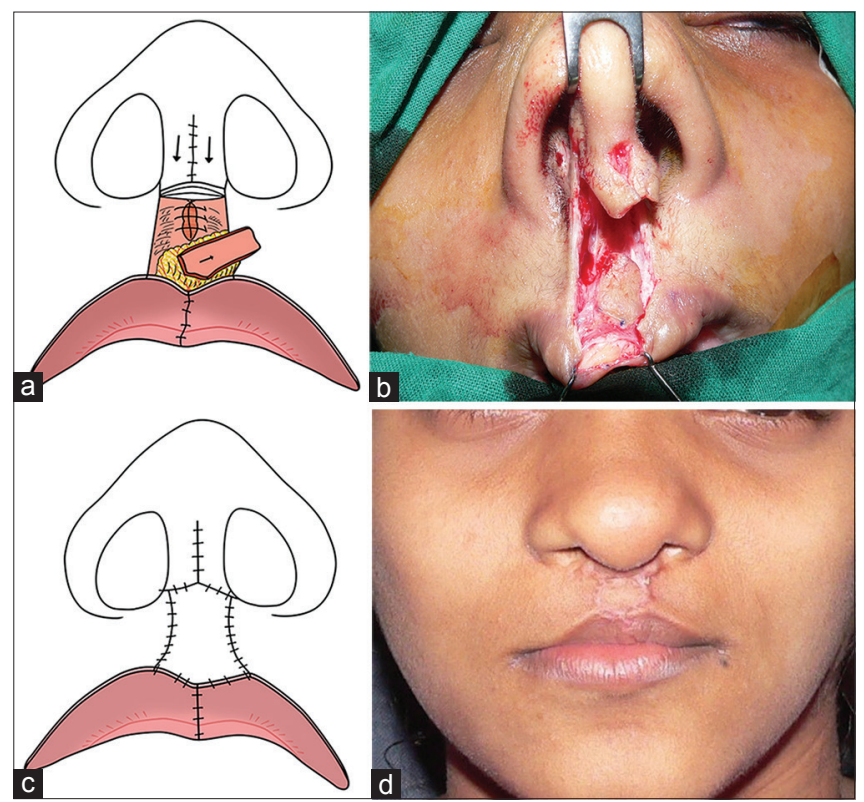

Figure 3: (a) Prolabial flap raised and islanded on a subcutaneous pedicle near the vermilion border. (b) Exposure obtained after raising the island prolabial flap to recreate the muscle sling. (c) After closure of the lip and rhinoplasty incisions in the same patient. (d) Appearance of the same patient at 3 months

coverage was continued for the $1^{\text {st }}$ post-operative day followed by a short course of oral antibiotics for 5 days postoperatively. Intranasal packing was removed on the $2^{\text {nd }}$ post-operative day, and the patient was discharged.

\section{RESULTS}

Since March 2012, 21 patients have undergone the subcutaneously pedicled island prolabial flap procedure. At the time of surgery, the average age was 19 years. There was a female predominance with a male-to-female ratio of 1:2. The follow-up period ranged from 8 to 41 months, with an average of 25 months. All patients were evaluated at 1 week, then at 3, 6 and 12 months postoperatively and yearly thereafter. The results were evaluated using pre- and post-operative clinical photographs in frontal, lateral and worm's eye views, complications and finally reoperation rates. Outcomes were documented based on patient satisfaction and evaluation by the authors [Figures 4(a-f), 5 (a-f) , 6(a-d), and supplemental digital content 1,2 and 3].

There were no post-operative complications such as airway obstruction, bleeding, infection, flap necrosis or wound disruption. Late follow-up shows good nasal symmetry with improved nasolabial and nasofacial relationship. There was no evidence of hypertrophic scars, trapdoor scars, nasal asymmetry and none of the

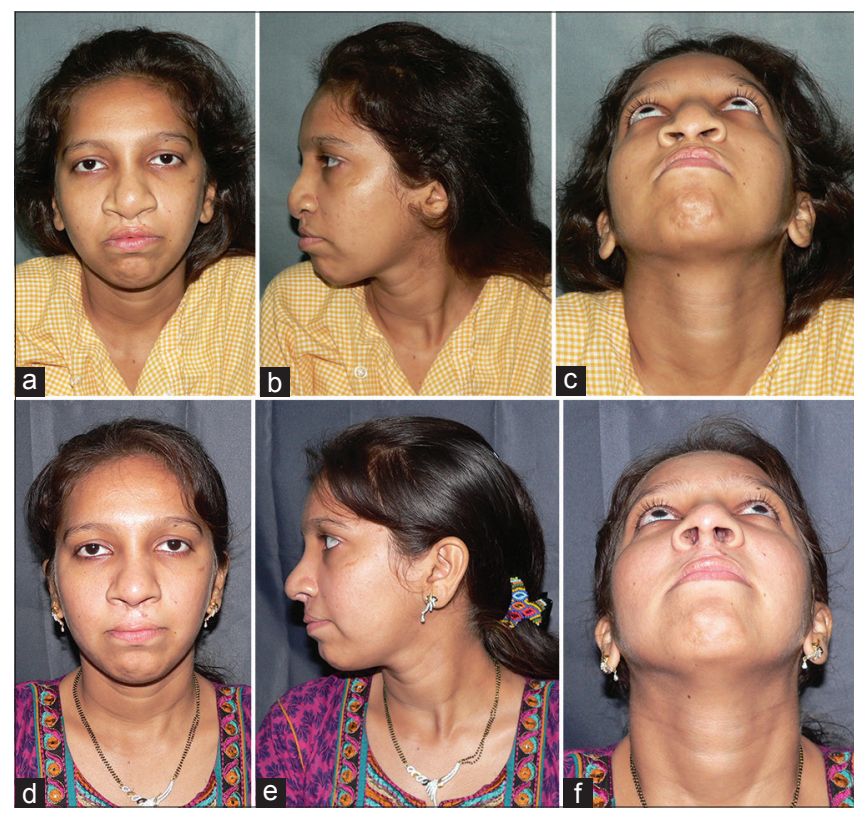

Figure 4: (a) Pre-operative frontal view of patient with wide prolabium and typical nasal deformity. (b) Pre-operative lateral view of a patient showing severely short columella. (c) Pre-operative worms' eye view of the same patient. (d) Post-operative frontal view after 1 year showing well-settled scar with aesthetically pleasing Cupid's bow and philtrum. (e) Post-operative lateral view at 1 year showing good tip projection. (f) Post-operative worms' eye view at 1 year showing good columellar elongation

patients required further touch-up or revision procedures for the lip. Only one patient, a 13-year-old girl, required a revision rhinoplasty with costochondral graft 3 years after the initial lip-nose revision.

The objective criteria considered in the evaluation by the authors included improvement of philtral ridge projection, symmetry of philtral column and nasal sill and white roll continuity [Table 2]. The authors' assessment judged $15(71.4 \%)$ patients as having an excellent outcome and $6(28.5 \%)$ patients as having a good outcome. The patients' satisfaction was assessed at 6 months postoperatively to record their impression of the aesthetic improvement after our procedure [Table 3]. The patients' self-assessment indicated that the aesthetic appearance was very much improved in $12(57 \%)$ and improved in $9(42.8 \%)$. No patient judged their aesthetic appearance as unchanged or worse. Patients' overall satisfaction scoring was also high, with 14 (66.6\%) very satisfied and 7 (33.3\%) satisfied with the outcome. No patients judged their outcomes as neutral or dissatisfied [Table 3].

\section{DISCUSSION}

There is currently a great deal of debate and variability of the surgical techniques utilised for the repair of secondary deformities of bilateral cleft lip and nose. However, the 
Mokal and Desai: Islanded pedicle flap technique for secondary correction of bilateral cleft lip nasal deformity.

Table 2: Authors' lip assessment score

\begin{tabular}{|c|c|c|c|c|c|c|c|c|c|c|c|}
\hline $\begin{array}{l}\text { Patient } \\
\text { number/name }\end{array}$ & $\begin{array}{c}\text { Cupid's } \\
\text { bow } \\
\text { symmetry }\end{array}$ & $\begin{array}{c}\text { Philtral } \\
\text { column } \\
\text { width }\end{array}$ & $\begin{array}{l}\text { White roll } \\
\text { continuity }\end{array}$ & $\begin{array}{c}\text { Central } \\
\text { vermilion } \\
\text { fullness }\end{array}$ & $\begin{array}{c}\text { Nostril } \\
\text { sill } \\
\text { width }\end{array}$ & $\begin{array}{l}\text { Nostril sill } \\
\text { symmetry }\end{array}$ & $\begin{array}{l}\text { Lat. Lip } \\
\text { height }\end{array}$ & $\begin{array}{c}\text { Lat lip } \\
\text { symmetry }\end{array}$ & $\begin{array}{c}\text { Orbicularis } \\
\text { oris } \\
\text { competence }\end{array}$ & $\begin{array}{l}\text { Quality } \\
\text { of scar }\end{array}$ & $\begin{array}{c}\text { Total } \\
\text { score } \\
\text { out of } 40\end{array}$ \\
\hline 1. $P C$ & 3 & 4 & 4 & 4 & 4 & 4 & 4 & 4 & 4 & 3 & 38 \\
\hline 2. $M$ & 4 & 4 & 4 & 4 & 4 & 4 & 4 & 4 & 4 & 4 & 40 \\
\hline 3. AJ & 4 & 4 & 4 & 4 & 4 & 4 & 4 & 4 & 4 & 4 & 40 \\
\hline 4. SP & 3 & 4 & 4 & 3 & 3 & 4 & 3 & 3 & 4 & 3 & 34 \\
\hline 5. NJ & 4 & 4 & 4 & 4 & 4 & 4 & 4 & 4 & 4 & 4 & 40 \\
\hline 6. $P G$ & 3 & 4 & 4 & 4 & 4 & 4 & 4 & 4 & 4 & 4 & 40 \\
\hline 7. JN & 3 & 4 & 3 & 4 & 4 & 4 & 4 & 4 & 4 & 3 & 37 \\
\hline 8. JK & 4 & 4 & 4 & 4 & 4 & 4 & 4 & 4 & 4 & 4 & 40 \\
\hline 9. NF & 4 & 4 & 4 & 3 & 4 & 4 & 4 & 3 & 4 & 4 & 38 \\
\hline 10. $P R$ & 4 & 4 & 4 & 4 & 4 & 4 & 4 & 4 & 4 & 4 & 40 \\
\hline 11. VS & 3 & 4 & 3 & 3 & 4 & 3 & 3 & 3 & 4 & 3 & 33 \\
\hline 12. $\mathrm{O}$ & 3 & 4 & 4 & 4 & 4 & 4 & 4 & 4 & 4 & 4 & 39 \\
\hline 13. RP & 3 & 2 & 2 & 3 & 4 & 4 & 3 & 3 & 3 & 2 & 29 \\
\hline 14. SB & 3 & 4 & 3 & 4 & 3 & 3 & 3 & 3 & 4 & 3 & 33 \\
\hline 15. BP & 3 & 3 & 4 & 4 & 4 & 4 & 3 & 3 & 4 & 3 & 35 \\
\hline 16. RW & 3 & 4 & 3 & 3 & 4 & 4 & 4 & 3 & 4 & 3 & 36 \\
\hline 17. SR & 4 & 4 & 3 & 4 & 3 & 4 & 3 & 4 & 3 & 3 & 36 \\
\hline 18. AS & 4 & 4 & 4 & 3 & 4 & 4 & 3 & 3 & 4 & 3 & 36 \\
\hline 19. AS & 3 & 3 & 3 & 3 & 3 & 3 & 3 & 3 & 3 & 3 & 30 \\
\hline 20. SR & 3 & 4 & 3 & 3 & 4 & 4 & 4 & 3 & 4 & 4 & 36 \\
\hline 21. YS & 3 & 4 & 4 & 3 & 4 & 3 & 4 & 3 & 2 & 4 & 34 \\
\hline Overall rating & \multicolumn{11}{|c|}{ Post-operative 6 months } \\
\hline Excellent & \multicolumn{11}{|c|}{15} \\
\hline Good & \multicolumn{11}{|c|}{6} \\
\hline Fair & \multicolumn{11}{|c|}{0} \\
\hline Poor & \multicolumn{11}{|c|}{0} \\
\hline Total & \multicolumn{11}{|c|}{21} \\
\hline
\end{tabular}

Scoring - 1: Lowest and 4: Highest for each individual parameter. Total score - 31-40: Excellent, 21-30: Good, 11-20: Fair, 0-10: Poor

Table 3: Patient self-assessed scoring system

\begin{tabular}{lc}
\hline & Post-operative 6 months \\
\hline Aesthetic improvement rating & 12 \\
Very much improved & 9 \\
Improved & 0 \\
No change & 0 \\
Worse & 21 \\
Total & \\
Overall satisfaction score & 14 \\
Very satisfied & 7 \\
Satisfied & 0 \\
Neutral & 0 \\
Dissatisfied & 21 \\
Total &
\end{tabular}

principles are fairly well established, namely symmetry, muscle continuity, proper philtral size and shape, adequate median tubercle, columellar lengthening, increasing nasal tip projection and correcting the flared alar bases. Restoration of facial aesthetic balance between the nose, lip and chin in these patients is best done as a single stage, in which both the lip and nose are addressed simultaneously. It also reduces the total number of surgeries the patient has to endure.
The optimal timing for lip revision surgery is at the time of secondary rhinoplasty, which is performed after completion of nasal skeletal growth, which is 16-17 years in girls and 17-18 years in boys. All of our patients, except three, were over these age parameters. However, in cleft patients with severe deformity, much earlier correction without nasal bone osteotomies is a long-established practice..$^{[9]}$ These children suffer low self-esteem, are socially backward and may even be taunted by their schoolmates, resulting in poor academic achievements. Hence, we went ahead with nasal correction in these three patients who were 12,13 and 14 years of age, respectively [Figure 5a-f]. Of these, only one patient required a revision rhinoplasty 3 years later.

The decision on whether to use our subcutaneously pedicled island flap technique for philtral reconstruction was based primarily on the quality of the available prolabial tissue. Those patients with a wide prolabium of adequate width and height were considered as candidates for this technique. In those patients with horizontally tight and vertically short upper lip along with central vermilion 
Mokal and Desai: Islanded pedicle flap technique for secondary correction of bilateral cleft lip nasal deformity.

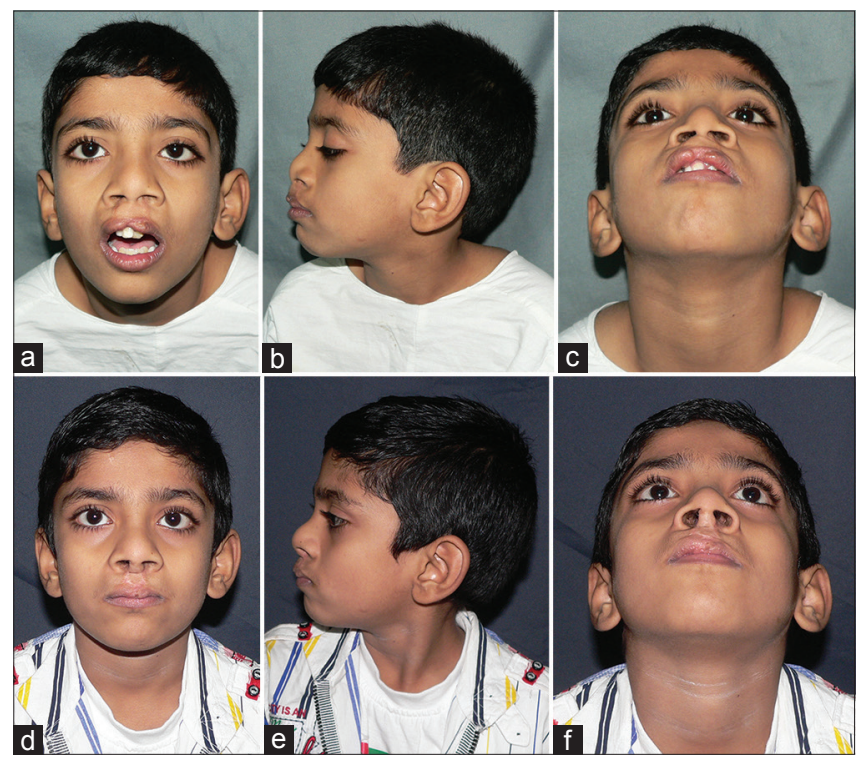

Figure 5: (a) Pre-operative frontal view of a 12-year-old boy with typical lip-nose deformity. (b) Pre-operative lateral view of a same patient showing flattened nose. (c) Pre-operative worms' eye view of the same patient.

(d) Post-operative frontal view after 5 months after lip-nose revision and alveolar bone grafting. (e) Post-operative lateral view showing good tip projection. (f) Post-operative worms' eye view showing aesthetically pleasing Cupid's bow and well-settled scars

deficiency, we prefer to do an Abbe flap and concomitant rhinoplasty. ${ }^{[10]}$

Since the open rhinoplasty approach required for simultaneous nasal correction effectively eliminates the vascular supply to the prolabium through the columellar artery, surgeons have endeavoured to find a solution such as using the prolabial skin as a hinge flap based on the vermilion. This allows tailoring of the philtrum and recreation of the orbicularis oris muscle sling; however, the white roll deformity and vermilion tubercle correction cannot be done simultaneously since the blood supply enters through the lower end of the philtrum in these cases. Thus, the patient will require another surgical procedure which defeats the purpose of doing lip-nose revision as a 'single-stage' procedure.

The alternative to the above technique is to raise the entire 'embryological unit' of the prolabium in continuity with the columella, for single-stage open tip rhinoplasty and concomitant lip repair. ${ }^{[1]}$ This is a commonly used procedure by many surgeons and was used by us before developing the current technique. Although this technique provides exposure for muscle approximation, allows revision of the white roll and vermilion scars and tailoring of the prolabium for philtrum reconstruction, we encountered several problems which left us unsatisfied with this method. Chief amongst these was the tenting of the skin at the nasolabial or columella-lip angle once the flap was sutured back. In his anatomical dissection around the nasolabial angle, $\mathrm{Wu}^{[12]}$ showed that the angle is maintained by a ligament from the subcutaneous tissue to the anterior nasal spine. Whenever the columella-prolabium complex is raised, the nasolabial angle tends to be flattened after operation. Some authors take a tuck-down suture between the skin and the anterior nasal spine at this point to recreate the angle. However, this further jeopardises the vascularity of an already long and narrow flap and is, in our opinion, not a suitable solution. Another issue with this method is that there is often inadequate columellar lengthening as we are constrained by the length of the original prolabial segment. To make up the possible shortage, we have to rely on pulling down the nasal dorsal skin to the tip, and the tip skin to the columella which often puts the skin over the augmented nasal tip under a fair amount of tension while not providing sufficient columellar length. All these lead to a poor result, especially in the lateral profile.

To summarise, the long flap has poor tip vascularity, tension at lower end subsequent to the columellar lengthening and when sutured back results in tenting at the nasolabial junction and destroys the lip-columellar angle.

Our dissatisfaction with the established methods led us to the idea of using the prolabium as an island of skin raised on a subcutaneous pedicle which has its base at the vermilion-cutaneous junction. The idea of a prolabial island was proposed by Noordoff in 1989, who used it for a one-stage reconstruction. ${ }^{[13]}$ Microscopic dissection of the prolabium as an island pedicle flap and interdigitation of the two-forked flap between the columella and prolabium for primary elongation was done. It was thereafter abandoned because it was deemed technically too complicated.

We propose that the bilateral cleft lip deformity needs correction at both the upper and lower end of the philtrum, as well as muscle re-approximation. With this in mind, the senior author (NJM) developed the prolabial flap as a skin island based on a caudal subcutaneous pedicle near the vermilion-cutaneous junction. This is a random pattern flap based on the underlying subcutaneous vascular supply, which in the face allows flaps to be raised with length to breadth ratios up to 3:1 or more. ${ }^{[14]}$ Two issues are of major concern while raising this flap. One being 
Mokal and Desai: Islanded pedicle flap technique for secondary correction of bilateral cleft lip nasal deformity.

that it is based on the subcutaneous tissues situated in the midline which maybe scarred by the previous primary lip repair. Another concern is in patients who may have had the flap previously raised (subcutaneous dissection with base superiorly) at the time of primary repair. Since this is a random pattern flap on the face which has an extremely robust subcutaneous vascularisation pattern, we feel that judicious dissection and leaving an adequate pedicle of healthy tissue can address both problems. Thus, judicious patient selection and careful dissection is unlikely to lead to any complications such as flap necrosis.

The IPF allows us to create the philtral aesthetic unit of the required dimensions while permitting white roll and vermilion advancement flaps from the lateral lip elements to reconstruct the Cupid's bow. In addition, it provides the surgeon with adequate exposure to mobilise and suture the orbicularis oris muscles across the midline as the subcutaneous pedicle is based near the vermilion end. Dynamic correction of orbicularis oris muscle sling results are shown in Figure 6(a-d). All scars are placed in the natural contours of the lip aesthetic units, and the scars settle well in the long term. The additional work to dissect the subcutaneously pedicled island flap does not greatly add to the time and complexity of the procedure. The lateral portions of the remaining prolabial tissue can be used for columellar elongation if required, or as de-epithelialised flaps for augmenting the central vermilion tubercle. The technique of using the forked flaps from the prolabium as described by Millard for columella lengthening is a very reasonable and useful method because it supplies adequate and similar type of tissue to lengthen the columella and at the same time allows the prolabium to be shaped to philtrum dimensions and the bilateral lip scars to be revised. ${ }^{[15]}$ As we use only half to one-third of the actual length of the forked flaps, we have not encountered any problem with vascularity at the flap tips. The use of prolabial skin for columella borrows lip

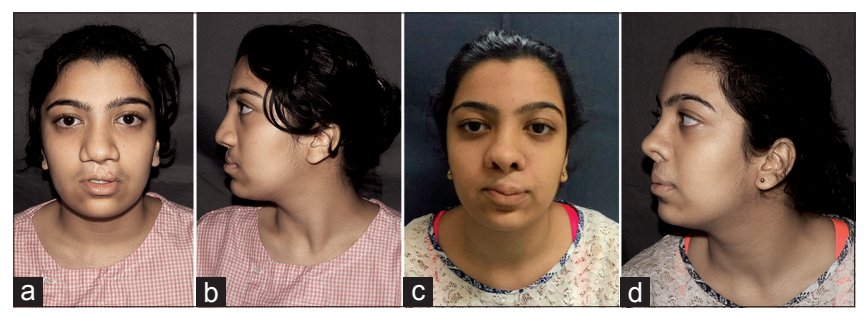

Figure 6: (a) Pre-operative frontal view of a patient with bilateral cleft lip-nose deformity. (b) Pre-operative lateral view of a patient with bilateral cleft lip-nose deformity. (c) Post-operative frontal view video demonstrating correction of the whistle deformity. (d) Post-operative lateral view of the same patient tissue into the nose, which might seem at odds with the currently accepted practices in the United States and Europe. However, we frequently need the extra skin as we commonly face the problem of true shortage of columellar skin after insertion of the columellar strut cartilage graft. This is because these patients have not undergone primary rhinoplasty at the time of primary lip repair. Hence, with growth, there is no columellar elongation, and the nose remains attached to the lip. Since both columellar and prolabium are derived from the same embryological unit, the cosmesis in terms of colour and texture match is acceptable.

The disadvantage of using the forked flaps is the nexus of scars formed at the base of the columellar base. However, we have not found this to be a significant aesthetic issue [Figures $4 \mathrm{f}, 5 \mathrm{f}$ and $6 \mathrm{c}$ ] in our series of patients.

\section{CONCLUSIONS}

Although a multitude of methods for reconstructing the philtrum have been described, no single procedure has achieved completely satisfactory results. Our prolabial flap technique has the advantages that the cosmetic unit of the philtrum can be defined, the orbicularis oris muscle sling can be recreated, white roll and vermilion flaps can be advanced from the lateral elements to reconstruct the Cupid's bow, all scars are placed along the borders of the facial aesthetic units and finally excess prolabial tissue can be used as forked flaps or to add bulk to the central vermilion tubercle. Thus, it is a holistic approach to achieve a balanced nasal tip, columella and lip relationship for the comprehensive correction of the bilateral cleft lip and nasal deformity. We do stress that, to successfully use the IPF technique, there must be ample prolabial tissue, namely 'Rob Peter to pay Paul, but only if Paul can afford it'. ${ }^{[16]}$ In cases where there is significant tissue shortage, we prefer to use an Abbe flap to recreate the philtrum and give an upper lip pout. ${ }^{[10]}$

\section{Acknowledgement}

The authors would like to thank Dr. Mukund Thatte for his guidance.

\section{Declaration of patient consent}

The authors certify that they have obtained all appropriate patient consent forms. In the form the patient(s) has/have given his/her/their consent for his/her/their images and other clinical information to be reported in the journal. 
Mokal and Desai: Islanded pedicle flap technique for secondary correction of bilateral cleft lip nasal deformity.

The patients understand that their names and initials will not be published and due efforts will be made to conceal their identity, but anonymity cannot be guaranteed.

\section{Financial support and sponsorship}

Nil.

\section{Conflicts of interest}

There are no conflicts of interest.

\section{REFERENCES}

1. Mulliken JB. Correction of the bilateral cleft lip nasal deformity: Evolution of a surgical concept. Cleft Palate Craniofac J 1992;29:540-5.

2. Mulliken JB. Repair of bilateral complete cleft lip and nasal deformity-State of the art. Cleft Palate Craniofac J 2000;37:342-7.

3. Salyer KE, McComb H. Discussion on primary repair of the bilateral cleft lip nose: A ten year review. Plast Reconstr Surg 1986;77:714-6.

4. Khandekar B, Srinivasan S, Mokal NJ, Thatte MR. Anthropometric analysis of lip-nose complex in Indian population. Indian J Plast Surg 2005;38:128-31.

5. Potter J. Some nasal tip deformities due to alar cartilage abnormalities. Plast Reconstr Surg (1946) 1954;13:358-66.

6. Millard DR Jr. Columella lengthening by a forked flap. Plast
Reconstr Surg Transplant Bull 1958;22:454-7.

7. Millard DR Jr. Closure of bilateral cleft lip and elongation of columella by two operations in infancy. Plast Reconstr Surg 1971;47:324-31.

8. Mokal NJ, Prabhash, Kale C. Composite correction of a unilateral cleft lip nose deformity and alveolar bone grafting. Indian J Plast Surg 2009;42 Suppl: S71-8.

9. Jackson IT. Repair of secondary cleft lip and nose deformities. In: McCarthy JG, editor. Current Therapy in Plastic Surgery. $1^{\text {st }}$ ed., Vol. 11. Philadelphia: W.B. Saunders Elsevier; 2006. p. 458-61.

10. Mokal NJ, Juneja M. Secondary bilateral cleft lip-nose deformity correction by rhinoplasty with simultaneous Abbe flap. Indian J Plast Surg 2014;47:20-4.

11. Trott JA, Mohan N. A preliminary report on one stage open tip rhinoplasty at the time of lip repair in bilateral cleft lip and palate: The Alor Setar experience. Br J Plast Surg 1993;46:215-22.

12. Wu WT. The oriental nose: An anatomical basis for surgery. Ann Acad Med Singapore 1992;21:176-89.

13. Noordoff MS. Primary Elongation of the Columella in Bilateral Cleft Lip and Palate with a Prolabial Island Pedicle Flap. Paper Presented at: $6^{\text {th }}$ International Congress on Cleft Palate and Related Craniofacial Anomalies, Jerusalem; 1989.

14. Cormack GC, Lamberty GH. The Arterial Anatomy of Skin Flaps. EdinburghChurchill Livingstone; 1986. p. 74.

15. Millard DR, Cassisi A, Wheeler JJ. Designs for correction and camouflage of bilateral clefts of the lip and palate. Plast Reconstr Surg 2000;105:1609-23.

16. Millard DR Jr. Plastic peregrinations. Plast Reconstr Surg (1946) 1950;5:26-53. 